\title{
Actual Study Regarding Quantitative Determination of Tetracyclines by Electrical Analysis Techniques and Methods Potentiometric sensors for tetracycline
}

\author{
NIKOLAOS MAVRITSAKIS ${ }^{1 *}$, VASILE EMIL URSU ${ }^{1 *}$, ELENA IONESCU2*, ANCA GANESCU ${ }^{3 *}$ \\ Universitatea 1 decembrie 1918, Alba Iulia,Facultatea de Drept si Stiinte Sociale, Departamentul de Educatie Fizica si Sport, 5 \\ Gabriel Bethlen, 510009, Alba Iulia, Romania \\ 2Universitatea de Medicina si Farmacie, 94-96 Ion Antonescu, Craiova, Romania \\ ${ }^{3}$ Universitatea din Craiova, Facultatea de Stiinte, Departamentul de Chimie, 107i Calea Bucuresti, Craiova, Romania
}

\begin{abstract}
Ion-selective electrodes have gained a wide applicability in pharmaceutical analysis and the literature has some data and their use for the determination of tetracyclines. Ion-selective electrodes for tetracycline were built using different electroactive materials and studied their performance. A working group from the Department of Analytical Chemistry of the University of Bucharest, in collaboration with a group of teaching staff from the Department of Chemistry at the Faculty of Sciences, University of Craiova, has developed and tested a series of ion-selective electrodes for tetracycline, [1], minocycline [2] and doxycycline [3]. These electrodes were tested for the determination of these tetracyclines from commercial tablets.
\end{abstract}

Keywords tetracycline, ion-selective electrodes, electroactive material.PVC, DOP.

Tetracyclines form a homogeneous class of broad spectrum antibiotics whose name derives from the tetracyclic structure of the common skeleton, octahydronaphthacene. The most prominent natural representatives of the class were discovered at intervals for several years: chlortetracycline - 1948, oxytetracycline - 1950, and tetracycline - 1953. Later a series of semisynthesis products were also obtained.

With metal ions, tetracyclines produce chelates that can be used to purify and separate them in their identification and dosing. It also appears that the prix-carbonyl structures bind very easily and stably the microelements essential to the development of microorganisms.

This is probably the mode of action against pathogens. Binding of metal cations prevents them from being used in the production of enzymes of tetracycline-sensitive microorganisms, antibacterial activity depending on the exhaustion efficiency of the trace elements of the environment.

It is easily characterized by their electronic absorption and fluorescence spectra. Their inconveniences consist of reduced water solubility and hydrolytic instability of the hydrochlorides, which make it difficult to administer the parent.

Unlike other classes of antibiotics, the structure of natural products can be modified without canceling antibacterial activity. A minimum of structural features possess 6-demethyl-6-deoxy-tetracycline, which is still an active antibiotic.

Tetracycline was initially obtained by reductive elimination of the chlorine atom by catalytic hydrogenation in the presence of a hydrate acceptor. Shortly after, S. alboniger was discovered in a Texas soil sample that produced it exclusively, and was later found in S. viridifaciens and aureofaciens culture medium in unirrigated biosynthesis.

Reducing the concentration or elimination of chloride ions in culture media, the presence of chlorination inhibitors (rodan, dithiocarbamates and benzthiazol-sulfamide) lead to the predominance of tetracycline.
Today, we work with selected mutants that produce only tetracycline regardless of the amount of chloride ions.

This is achieved by a standard biosynthesis where the fermentation phase actually takes about 120 hours at $27^{\circ}$ $\mathrm{C}$ and $\mathrm{pH}=6.5-6.8$ with aeration of 0.7-1.0 I air / medium • minute. The sugar source is made up of dextrinized starch and corn flour.

Protein coagulation at $\mathrm{pH}=1.5$ and introduction of soil from infusions facilitates filtration. Under these conditions, tetracycline is soluble butin danger of being inactivated by the acidic medium, which is why the filtration takes place rapidly and at a temperature of $10-15^{\circ} \mathrm{C}$.

The filtrate was adjusted to $\mathrm{pH} 7.7$ with ammoniacal solution when the tetracycline calcine complex precipitated and filtered. This complex is formed with calcium ions from $\mathrm{CaCO}_{3}$ about $1 \%$ in culture medium to buffer acidity from fermentation. It is used for the separation and purification of all tetracyclines due to water insolubility.

The filtrate contains amounts of vitamin B12 and can be used to separate it. Low vitamin content raises some problems of profitability.

The complex obtained is passed into water to avoid inactivation of the antibiotic in alkaline medium and the suspension is treated with oxalic acid to remove calcium as the insoluble oxalate which is removed.

Separation of the crude base is based on its relative solubility in concentrated aqueous solution. The acidic filtrate from the oxalic acid is adjusted to $\mathrm{pH}=4$ and the base precipitates.

Purification of the base and conversion to the hydrochloride is carried out by extraction with methanol and $\mathrm{AcOBu}$ solution of the antibiotic from the crude product, concentration of the extract and conversion of the base to the hydrochloride with concentrated $\mathrm{HCl}$. The formed salt is poorly soluble in the organic solvent solution and precipitates.

Tetracyclines are solid, crystallized, yellow-gold colored substances with chromosome groups in the molecule and 
have a bitter taste. Water solubility is reduced, by increasing the $\mathbf{p H}$ (greater than 8.5) they become more soluble.

They dissolve in some organic solvents and are very little soluble in ethers. Their salts (e.g., hydrochlorides) have higher solubility in water, butlower in some organic solvents (ether, chloroform, acetone). They are optically active substances. Facing light are photosensitive, generally exposed to light browning.

From a chemical point of view, tetracyclines are closely related to naphthalene, containing a linear 4-membered condensed ring system to which the general formula<smiles>[R]c1ccc(O)c2c1C([R])(O)C1C(=O)C3=C(O)C4C(=O)C(C(N)=O)=CC(N(C)C)C4C([R])C3C(=O)C21</smiles>

The chemical properties characteristic of these substances have been found to be due both to the naftacene core nucleus, to the superfine polynuclear hydrocarbon with linear condensed nuclei, and to the functional groups grafted on this nucleus, the chemical character of which imparts to the tetracyclines an amphoteric character.

Analyzing the general formula of tetracyclines as well as some degradation products resulting from the reactions performed in order to reveal their chemical structure, we noticed that a particular influence on the chemical behavior of tetracyclines exerts:

-phenolic $-\mathrm{OH}$ phenolic ring grafted at $\mathrm{C}_{10}$ of the fully aromatized $\mathrm{D}$ ring;

- enol-OH enriched at $\mathrm{C}_{10}$ ring $\mathrm{A}$;

-the group - $\mathrm{N}(\mathrm{CH} 3)_{2}$, the $\mathrm{C}_{4}$-grafted disulfide amine of ring $A$;

- the -CO-NH $\mathrm{NH}_{2}$ group grafted at the $\mathrm{C}_{2}$ of the ring $\mathrm{A}$;

Tetracyclines are both acidic due to the phenolic group to which the acidity of the enolic groups and the basic character of the secondary amine group are added.

Thus, tetracyclines are combinations of the character of amphoteric character manifested by the tendency to form salts with both acids and bases under the corresponding reaction conditions.

\section{Experimental part}

In the following, both a constructive and a performance characterization, an oxytetracycline sensitive electrode will be presented using the oxitetracycline complex with $\mathrm{K}_{2}$ $\left[\mathrm{Pt}(\mathrm{SCN}){ }_{6}\right]$ as an electroactive material.

\section{Realization of the electrode}

The PVC membrane was prepared by continuously stirring a solution of the oxytetracycline complex with $\mathrm{K}_{2}$ [Pt (SCN) ${ }_{6}$ ] in DOP with 5\% PVC solution and tetrahydrofuran and evaporation of the tetrahydrofuran. The proportions of the three components in the mixture were

\section{$43 \%$ PVC}

$50 \%$ dioctylphthalate (DOP)

$7 \%$ complex $\mathrm{K}_{2}$ [Pt (SCN) ${ }_{61}$, and oxytetracycline

The obtained membranes were fixed with Super Glue at the lower end of some glass bodies whose shape and size are shown in the figure below.

The electrical contact between the membrane and the internal reference electrode was achieved by means of an internal solution of $1 \mathrm{M} \mathrm{NaCl}$ containing $5 \cdot 10^{-3} \mathrm{~mol} \cdot \mathrm{L}^{-1}$ oxytetracycline which was introduced into the electrode body after membrane fixation. The electrodes were preconditioned in a $1 \cdot 10^{-3} \mathrm{~mol}$ solution $\cdot \mathrm{L}^{-1}$ Oxitetracycline for $24 \mathrm{~h} \mathrm{[4].}$

Particularly important in making the $\mathrm{Ag}, \mathrm{AgCl} / \mathrm{Cl}$ reference electrode, which was obtained by electrothermal deposition at $600^{\circ} \mathrm{C}$ of a layer of $\mathrm{AgCl}$ on silver wire [5].

Potentiometric measurements were performed in an electrochemical cell with 2 electrodes schematically represented as follows[6].

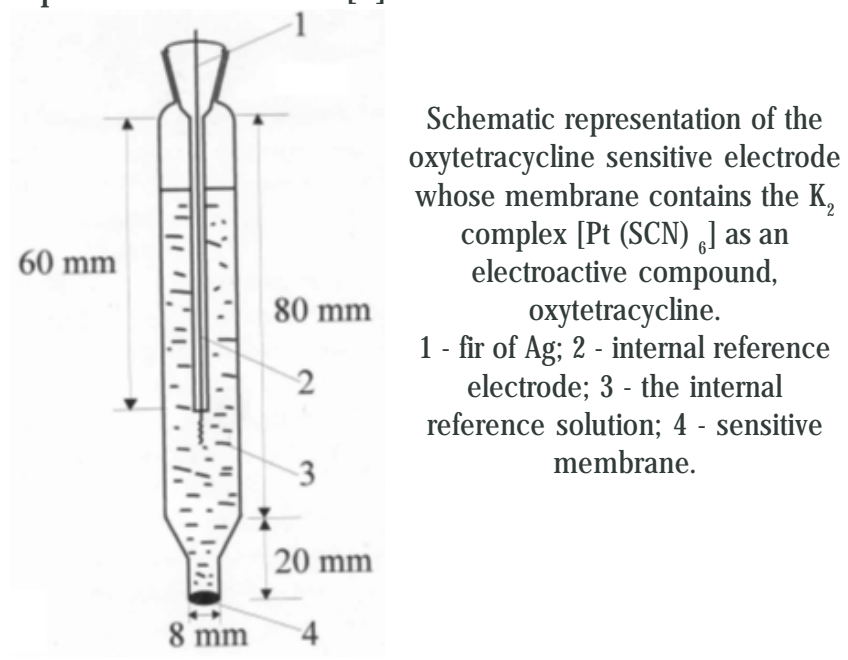

The electrochemical chain is:

Oxytetracycline sensitive electrode / Test solution / $\mathrm{NaCl}$ / $\mathrm{AgCl}, \mathrm{Ag} / \mathrm{Cl}-$

Between the external reference electrode and the test solution was made a bond with a saturated $\mathrm{NaCl}$ salt bridge.

\section{Results and discussions}

A membrane composition was varied to achieve a oxytetracycline sensitive electrode so as to obtain a response closest to that characteristic for the oxitetracycline cation $\left(\mathrm{OxTC}^{+}\right)$. As the complexing agent for the OxTc + cation, $\mathrm{K}_{2}\left[\mathrm{Pt}\right.$ (SCN) $\left.{ }_{6}\right]$.

For each membrane composition the preparation was repeated three times to check the reproducibility of the preparation processes.

The relative standard deviation was calculated and found to be $<0.5$. Finally, the membrane composition described above was chosen and the corresponding electrodes ( 3 specimens with the same membrane composition) were characterized for their performance over a two-month period [7].

In tables 1-4 below are presented the data on the evolution over time of the electrode response potential at different concentration levels $\left(10^{-5}, 10^{-4}, 10^{-3}, 10^{-2}\right) \mathrm{mol} / \mathrm{L}$, in order to establish of the electrode response time.

The graphical representation of the evolution of the electrode response path at the four selected concentration levels is shown in figures 1,2,3.

All these representations reveal that the response time for this type of electrodes is around 1 minute and that the response potential is very stable over time.

The response of the electrodes was checked by carrying out the voltage measurements on each electrolytic cell carried out on a concentration range of $1 \cdot 10^{-6}-5 \cdot 10^{-2} \mathrm{~mol}$ $/ L$, in which case the measured cell voltage is given by the equation:

$$
\text { Ecel = Eocel + RT / ZFlg [oxytetracycline]. }
$$

Potentiometric selectivity coefficients (table 5) were evaluated by the separate solution method.

The values obtained for these potentiometric selectivity coefficients point out that a series of monovalent and 


\begin{tabular}{|c|c|c|c|c|}
\hline Current number & $\begin{array}{c}\text { Time } \\
\mathrm{s}\end{array}$ & $\begin{array}{c}\text { electrode } \\
1 \\
\mathrm{E}, \mathrm{V} \text { vsAg, } \mathrm{AgCl} / \mathrm{Cl}^{-}\end{array}$ & $\begin{array}{c}\text { electrode } \\
2 \\
\mathrm{E}, \mathrm{V} \text { vsAg, } \mathrm{AgCl} / \mathrm{Cl}^{-}\end{array}$ & $\begin{array}{c}\text { electrode } \\
3 \\
\mathrm{E}, \mathrm{V} \\
\mathrm{vsAg}, \mathrm{AgCl} / \mathrm{Cl}^{-}\end{array}$ \\
\hline 1 & 0 & +0.000 & +0.000 & +0.000 \\
\hline 2 & 30 & +0.049 & +0.047 & +0.052 \\
\hline 3 & 60 & +0.050 & +0.048 & +0.053 \\
\hline 4 & 90 & $+0,051$ & +0.048 & +0.053 \\
\hline 5 & 120 & +0.051 & +0.048 & +0.053 \\
\hline 6 & 150 & +0.051 & +0.048 & +0.053 \\
\hline 7 & 180 & +0.051 & +0.048 & +0.053 \\
\hline 8 & 210 & +0.051 & +0.048 & +0.053 \\
\hline 9 & 240 & +0.051 & +0.048 & +0.053 \\
\hline 10 & 270 & +0.051 & +0.048 & +0.053 \\
\hline 11 & 300 & $+0,051$ & +0.048 & +0.053 \\
\hline 12 & 330 & +0.051 & +0.048 & +0.053 \\
\hline 13 & 360 & +0.051 & +0.048 & +0.053 \\
\hline 14 & 390 & +0.051 & +0.048 & +0.053 \\
\hline 15 & 420 & +0.051 & +0.048 & +0.053 \\
\hline 16 & 450 & +0.051 & +0.048 & +0.053 \\
\hline 17 & 480 & +0.051 & +0.048 & +0.053 \\
\hline 18 & 510 & +0.051 & +0.048 & +0.053 \\
\hline 19 & 540 & +0.051 & +0.048 & +0.053 \\
\hline 20 & 570 & +0.051 & +0.048 & +0.053 \\
\hline 21 & 600 & +0.051 & +0.048 & +0.053 \\
\hline
\end{tabular}

Table 1

EVOLUTION OF THE POTENTIAL OF IONSELECTIVE ELECTRODES OVER TIME. SETTING THE RESPONSE TIME TO A CONCENTRATION OF $1 \cdot 10-5$ MOL / L OXYTETRACYCLINE, 24 HOURS AFTER PREPARATION

\begin{tabular}{|c|c|c|c|c|}
\hline Current number & $\begin{array}{c}\text { Time } \\
\text { s }\end{array}$ & $\begin{array}{c}\text { Electrode } \\
1 \\
\text { E, V } \\
\text { Vs Ag, AgCl/Cl- }\end{array}$ & $\begin{array}{c}\text { Electrode 2 } \\
\text { E, V } \\
\text { Vs } \\
\mathrm{Ag}, \mathrm{AgCl} / \mathrm{Cl}^{-}\end{array}$ & $\begin{array}{c}\text { Electrode 3 } \\
\mathrm{E}, \mathrm{V} \\
\mathrm{Vs} \\
\mathrm{Ag}, \mathrm{AgCl} / \mathrm{Cl}\end{array}$ \\
\hline 1 & 0 & +0.000 & +0.000 & +0.000 \\
\hline 2 & 30 & +0.021 & +0.017 & +0.021 \\
\hline 3 & 60 & +0.022 & +0.018 & +0.022 \\
\hline 4 & 90 & +0.023 & +0.019 & +0.023 \\
\hline 5 & 120 & +0.023 & +0.020 & +0.024 \\
\hline 6 & 150 & +0.023 & +0.020 & +0.024 \\
\hline
\end{tabular}

EVOLUTION OF THE POTENTIAL OF ION-SELECTIVE ELECTRODES OVER TIME. SETTING THE RESPONSE TIME

TO A CONCENTRATION OF $1 \cdot 10^{-4} \mathrm{MOL} / \mathrm{L}$ OXYTETRACYCLINE, 24 HOURS AFTER PREPARATION

\begin{tabular}{|c|c|c|c|c|}
\hline 8 & 210 & +0.023 & +0.020 & +0.024 \\
\hline 9 & 240 & +0.023 & +0.020 & +0.024 \\
\hline 10 & 270 & +0.023 & +0.020 & +0.024 \\
\hline 11 & 300 & +0.023 & +0.020 & +0.024 \\
\hline 12 & 330 & +0.023 & +0.020 & +0.024 \\
\hline 13 & 360 & +0.023 & +0.020 & +0.024 \\
\hline 14 & 390 & +0.023 & +0.020 & +0.024 \\
\hline 15 & 420 & +0.023 & +0.020 & +0.024 \\
\hline 16 & 450 & +0.023 & +0.020 & +0.024 \\
\hline 17 & 480 & +0.023 & +0.020 & +0024 \\
\hline 18 & 510 & +0.023 & +0.020 & +0.024 \\
\hline 19 & 540 & +0.023 & +0.020 & +0.024 \\
\hline 20 & 570 & +0.023 & +0.020 & +0.024 \\
\hline 21 & 600 & +0.023 & +0.020 & +0.024 \\
\hline
\end{tabular}

\begin{tabular}{|c|c|c|c|c|}
\hline Current number & $\begin{array}{c}\text { Time } \\
\mathrm{s}\end{array}$ & $\begin{array}{c}\text { Electrode 1 } \\
\mathrm{E}, \mathrm{V} \\
\text { vs Ag, AgCl/Cl- }\end{array}$ & $\begin{array}{c}\text { Electrode 2 } \\
\mathrm{E}, \mathrm{V} \\
\text { VsAg, AgCl/Cl }\end{array}$ & $\begin{array}{c}\text { Electrode 3 } \\
\mathrm{E}, \mathrm{V} \\
\text { vsAg, AgCl/Cl- }\end{array}$ \\
\hline 1 & 0 & 0.000 & 0.000 & 0.000 \\
\hline 2 & 30 & -0.003 & -0.006 & -0.004 \\
\hline 3 & 60 & -0.004 & -0.008 & -0.005 \\
\hline 4 & 90 & -0.005 & -0.009 & -0.006 \\
\hline 5 & 120 & -0.005 & -0.009 & -0.006 \\
\hline 6 & 150 & -0.005 & -0.009 & -0.006 \\
\hline 7 & 180 & -0.005 & -0.009 & -0.006 \\
\hline 8 & 210 & -0.005 & -0.009 & -0.006 \\
\hline 9 & 240 & -0.005 & -0.009 & -0.006 \\
\hline 10 & 270 & -0.005 & -0.009 & -0.006 \\
\hline
\end{tabular}

Table 3

POTENTIAL EVOLUTION OF SELECTIVE ION ELECTRODES OVER TIME. DETERMINATION OF RESPONSE TIME AT A CONCENTRATION OF $1 \cdot 10^{-3}$ MOL / L OXYTETRACYCLINE 24 HOURS AFTER PREPARATION 


\begin{tabular}{|l|l|l|l|l|}
\hline 11 & 300 & -0.005 & -0.009 & -0.006 \\
\hline 12 & 330 & -0.005 & -0.009 & -0.006 \\
\hline 13 & 360 & -0.005 & -0.009 & -0.006 \\
\hline 14 & 390 & -0.005 & -0.009 & -0.006 \\
\hline 15 & 420 & -0.005 & -0.009 & -0.006 \\
\hline 16 & 450 & -0.005 & -0.009 & -0.006 \\
\hline 17 & 480 & -0.005 & -0.009 & -0.006 \\
\hline 18 & 510 & -0.005 & -0.009 & -0.006 \\
\hline 19 & 540 & -0.005 & -0.009 & -0.006 \\
\hline 20 & 570 & -0.005 & -0.009 & -0.006 \\
\hline 21 & 600 & -0.005 & -0.009 & -0.006 \\
\hline
\end{tabular}

\begin{tabular}{|c|c|c|c|c|}
\hline Current number & $\begin{array}{c}\text { Time } \\
\mathrm{s}\end{array}$ & $\begin{array}{c}\text { Electrode 1 } \\
\mathrm{E}, \mathrm{V} \\
\mathrm{Vs}, \mathrm{Ag}, \mathrm{AgCl} / \mathrm{Cl}-\end{array}$ & $\begin{array}{c}\text { Electrode 2 } \\
\mathrm{E}, \mathrm{V} \\
\mathrm{Vs}, \mathrm{Ag}, \mathrm{AgCl} / \mathrm{Cl}-\end{array}$ & $\begin{array}{c}\text { Electrode 3 } \\
\mathrm{E}, \mathrm{V} \\
\mathrm{Vs}, \mathrm{Ag}, \mathrm{AgCl} / \mathrm{Cl}\end{array}$ \\
\hline 1 & 0 & 0.000 & 0.000 & 0.000 \\
\hline 2 & 30 & +0.021 & +0.017 & +0.021 \\
\hline 3 & 60 & +0.022 & +0.018 & +0.022 \\
\hline 4 & 90 & +0.023 & +0.019 & +0.023 \\
\hline 5 & 120 & +0.023 & +0.020 & +0.024 \\
\hline
\end{tabular}

EVOLUTION OF ION-SELECTIVE ELECTRODES POTENTIAL OVER TIME. SETTING THE RESPONSE TIME TO A CONCENTRATION OF $1 \cdot 10^{-2} \mathrm{MOL} / \mathrm{L}$ OXYTETRACYCLINE, 24 HOURS AFTER PREPARATION

Table 3

Continuated

\begin{tabular}{|c|c|c|c|c|}
\hline 6 & 150 & +0.023 & +0.020 & +0.024 \\
\hline 7 & 180 & +0.023 & +0.020 & +0.024 \\
\hline 8 & 210 & +0.023 & +0.020 & +0.024 \\
\hline 9 & 240 & +0.023 & +0.020 & +0.024 \\
\hline 10 & 270 & +0.023 & +0.020 & +0.024 \\
\hline 11 & 300 & +0.023 & +0.020 & +0.024 \\
\hline 12 & 330 & +0.023 & +0.020 & +0.024 \\
\hline 13 & 360 & +0.023 & +0.020 & +0.024 \\
\hline 14 & 390 & +0.023 & +0.020 & +0.024 \\
\hline 15 & 420 & +0.023 & +0.020 & +0.024 \\
\hline 16 & 450 & +0.023 & +0.020 & +0.024 \\
\hline 17 & 480 & +0.023 & +0.020 & +0.024 \\
\hline 18 & 510 & +0.023 & +0.020 & +0.024 \\
\hline 19 & 540 & +0.023 & +0.020 & +0.024 \\
\hline 20 & 570 & +0.023 & +0.020 & +0.024 \\
\hline 21 & 600 & +0.023 & +0.020 & +0.024 \\
\hline
\end{tabular}

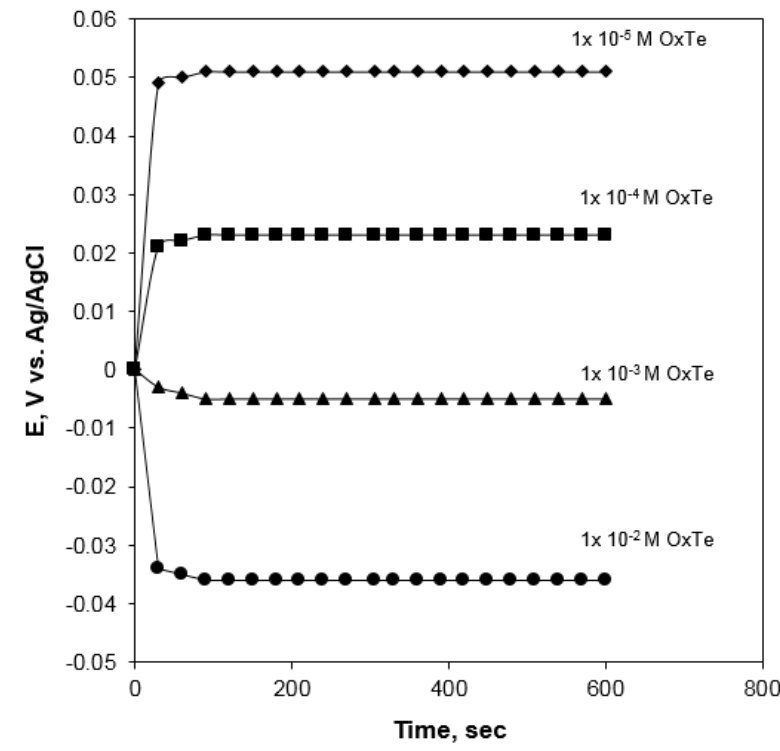

Fig. 1. Evolution of ion-selective electrode potential 1 over time at different levels of oxytetracycline concentrations. Setting the electrode response time

bivalent cations do not interfere with the other tetracyclines (tetracycline, doxycycline).

It also does not interfere with quaternary ammonium ion, often used in electrochemical measurements

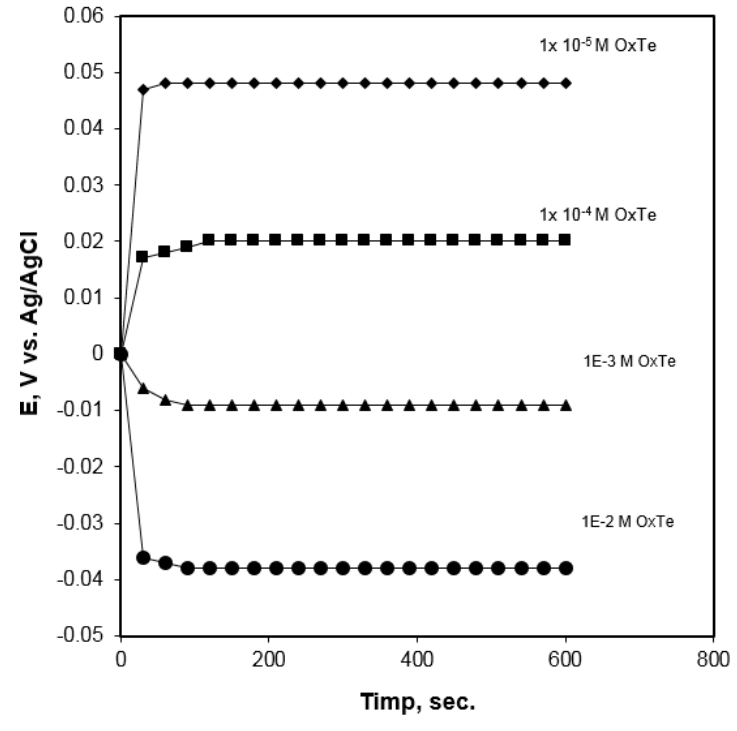

Fig. 2. Evolution of the potential of selective ion electrode 2 over time at various concentrations of oxytetracycline. Setting the response time

Studying the influence of $\mathrm{pH}$ on the electrode response was found to be unaffected by hydrogen ion activity in the $\mathrm{pH}$ range of 3 to 9 . 
Table 5

SELECTIVITY POTENTIOMETRIC COEFFICIENTS OBTAINED FOR ELECTRODE 1 USING THE SEPARATE SOLUTION METHOD

\begin{tabular}{|c|c|c|}
\hline Current number & Interferent species & $\mathrm{K}_{\mathrm{i}, \mathrm{j}}^{\mathrm{pot}}$ \\
\hline 1 & $\mathrm{Li}^{+}$ & 0.00025 \\
\hline 2 & $\mathrm{Na}^{+}$ & 0.00051 \\
\hline 3 & $\mathrm{~K}^{+}$ & 0.00055 \\
\hline 4 & $\mathrm{Rb}^{+}$ & 0.00062 \\
\hline 5 & $\mathrm{NH}_{4}^{+}$ & 0.00058 \\
\hline 6 & $\mathrm{Ca}^{2+}$ & 0.00049 \\
\hline 7 & $\mathrm{Mg}^{2+}$ & 0.00038 \\
\hline 8 & $\mathrm{Cd}^{2+}$ & 0.00031 \\
\hline 9 & $\mathrm{~Pb}^{2+}$ & 0.00021 \\
\hline 10 & $\mathrm{Mn}^{2+}$ & 0.00018 \\
\hline 11 & $\mathrm{Fe}^{2+}$ & 0.00011 \\
\hline 12 & $\mathrm{CO}^{2+}$ & 0.00007 \\
\hline 13 & $\mathrm{Ni}^{2+}$ & 0.00015 \\
\hline 14 & $\mathrm{Cu}^{2+}$ & 0.00005 \\
\hline 15 & $\mathrm{Zn}^{2+}$ & 0.00007 \\
\hline 16 & Tetraciclină & 8.014 \\
\hline 17 & Minociclină & 7.122 \\
\hline 18 & Doxiciclină & 6.935 \\
\hline 19 & $\left(\mathrm{CH}_{3}\right)_{4} \mathrm{~N}$ & 0.00062 \\
\hline
\end{tabular}

\section{Conclusions}

The ion-sensitive polymer membrane based on $\mathrm{K}_{2}[\mathrm{Pt}$ ( $\mathrm{SCN})_{6}$ ], oxytetracycline complex, made and characterized, have been shown to provide good results in quantitative analytical determinations possessing a very close response to nernstian with a range of linearity between $1 \cdot 10^{-5}$ and $1 \cdot 10^{-2} \mathrm{~mol} / \mathrm{L}$.

The electrode exhibits an optimal response 4-5 days after the realization although the lifetime is longer than 50 days, but the electrode slope decreases by about 30\% during this time

The electrode may be used over the period, but calibration is required before each set of determinations.

The time instability of the electrode response is explained by the fact that the internal solution containing oxytetracycline in $\mathrm{NaCl}$ is unstable, the antibiotic degrading over time.
For the quantitative measurements of oxytetracycline the $\mathrm{pH}$ of the solution to be analyzed should be adjusted to a value in the range 3-9

The ion-selective PVC membrane based on the inventive oxytetracycline- $\mathrm{K}_{2}\left[\mathrm{Pt}\left(\mathrm{SCN}_{16}\right]\right.$ ion complexing electrode was used to determine oxytetracycline by direct potentiometry from commercial capsules and satisfactory results were obtained, with retrievals ranging from $96.9 \%$ to $101.6 \%$

Existing excipients in oxytetracycline capsules do not interfere with determination, and the proposed method is simple, cheap and fast.

\section{References}

1. C. DAESCU., Chimia si Tehnologia Medicamentelor, Editura Didactica si Pedagogica, Bucuresti, 1994.

2. *** Farmacopeea Romana, Editura Medicala, Bucuresti, 1993

3. IULIA GABRIELA DAVID, E. E. IORGULESCU, I. GH. TÃNASE., Conferinta de Chimie si Inginerie Chimica, vol III, 4-121, 1997.

4. IULIA GABRIELA DAVID., Teza de doctorat, Universitatea Bucuresti, 1997.

5. I. GH. TANASE, M. CRISTACHE-SAVU, ADRIANA SCARLAT, ILEANA POPESCU, G. L. RADU., Roumanian Biotehnological, Letters, 5 (2), $139,2000$.

6. I. GANESCU, VARHELYI., Rev. Roumaine Chem, 32, 255, 1987.

7. GANESCU, I., PAPA, I., GANESCU, A., CHIRIGIU, L., Rev. Chim. (Bucharest), 51, no. 3, 2000.

8.YABE, J., NAKAYAMA, S.M.M., IKENAKA, Y., YOHANNES, Y.B., BORTEYSAM, N., OROSZLANY, B., MUZANDU, K., CHOONGO, K., KABALO, A.N., NTAPISHA, J., MWEENE, A., UMEMURA, T., ISHIZUKA, M., Chemosphere, 119, 2015, p. 941.

9. MATTIO, E., ROBERT-PEILLARD, F., BRANGER, C., PUZIO, K., MARGAILLAN, A., BRACH-PAPA, C., KNOERY, J., BOUDENNE, J.L., COULOMB, B., Talanta, 168, 2017, p. 298.

10.. LUPU, S., BALAURE, P.C., COSTEA, I., LETE, C., MARIN, M., ENACHE, C., Rev. Chim. (Bucharest), 60, no. 3, 2009, p. 248

11. BUICA, G.O., UNGUREANU, E.M., BIRZAN, L.,RAZUS, A.C., MANDOC (POPESCU), L.R., J. Electroanal. Chem., 693, 2013, p. 67

12. ARNOLD, G.-L., STEFAN-VAN-STADEN, R.I., MOLDOVEANU-IONITA, I.,UNGUREANU, E.M., POPESCU -MANDOC, L.R., J . Electrochem. Soc., 163, no. 10, 2016, p. B563

13.1. SINGH, R., GAUTAM, N., MISHRA, A., GUPTA, R., Indian J. Pharmacol., 43, no. 3, 2011, p. 246

14. 13. DUAN, H., ZHANG, N., GONG, Z., LI, W., HANG, W., Spectrochim. Acta $B, 120,2016$, p. 63

15. 24. BUICA, G.O., LAZAR, I.G., SAINT-AMAN, E., TECUCEANU, V., DUMITRIU, C., ANTON, I.A., STOIAN, A.B., UNGUREANU, E.M., Sens. Actuator. B-Chem., 246, 2017, p. 434

Manuscript received: 6.10 .2018 